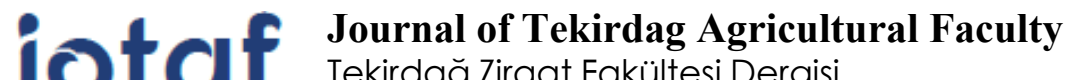 \\ Tekirdağ Ziraat Fakültesi Dergisi
}

\section{Changing Scenario of Crop Diversification in Nepal: Delineating The Role of Trade Openness, Urbanization and Rural Infrastructure}

\author{
Bidyut Kumar Ghosh
}

\begin{abstract}
Crop diversification in the farming sectors has been accepted to be a wise strategy for augmenting the farmers' income level as well as for mitigating the challenges for climatic change worldwide. Considering the importance of crop diversification both from the view points of farmers and environmental aspects, this paper using the secondary data tries to find out the pattern of growth of area, production, and yield of the major crops in Nepal, and at the same time, it makes an attempt to examine the crop pattern changes in Nepal along with its determining factors including both demand and supply-side factors. The growth analysis reveals that for most of the crops the second sub-period of 1986 - 2007 was the best in terms of the growth of production as compared to the other twosubperiods (1961 - 1985 and 2008 - 2017). The crop pattern of Nepal over the years shows that though the food grain crops still dominate the crop mix of the economy, there is clear evidence of necessary intercrop substitution where the traditional food grain crops are being replaced by commercial cash crops. Tea has come up with a big way in Nepal commercial cash crop production. Also, the crop diversification indices measured by the Herfindahl index and Shannon index, show a rising trend in diversification pattern during the nineties. Urbanization, better infrastructural supports in terms of better technology, irrigation coverage has been found to provide a significant positive impact on the diversification process. However, the trade openness is not found to be beneficial for Nepal's agricultural sector diversification process as does the policy reforms in the post-political reforms.
\end{abstract}

Keywords: Crop diversification, Trade openness, Infrastructure, Urbanization, Growth, Beta regression

\footnotetext{
1 Corresponding Author: Bidyut Kumar Ghosh, Department of Commerce, Manipal Academy of Higher Education, Manipal,India. E-mail: bidyutbwn@gmail.com (iD) OrcID: 0000-0002-7835-8171.

Atıf/Citation: Ghosh B.K., Changing Scenario of Crop Diversification in Nepal: Delineating the Role of Trade Openness, Urbanization and Rural Infrastructure. Tekirdağ Ziraat Fakültesi Dergisi, 18 (4), 599-612

(CBu çalışma Tekirdağ Namık Kemal Üniversitesi tarafından Creative Commons Lisansı (https://creativecommons.org/licenses/by-nc/4.0/) kapsamında yayınlanmıștır. Tekirdağ 2021
} 


\section{Introduction}

Though the share of agriculture, forestry, and fishing to the Gross Domestic Product (GDP) of Nepal has been reducing continuously since time long, still the sector holds the backbone of the Nepalese economy. According to the World Bank, the share of this sector has decreased from $64.58 \%$ in 1965 to $48.85 \%$ in 1985 , further to $38.24 \%$ in 2000, and finally reached $25 \%$ in 2018 . However, rural economy vis-à-vis the agriculture sector is predominant of economic activities and has the potential to provide stable and productive jobs to the people of Nepal. As it is evident from the International Labour Force (ILO) data that the agricultural sector remains the largest employer to the country's labor force as $82.33 \%$ of the labor force was employed in this sector in 1991, $75.68 \%$ in 2000 and $70.1 \%$ in 2018 .

Of late, the climatic changes through the rising mean temperature has also become a significant cause of concern for raising the agricultural gross domestic product (Acharya and Bhatta, 2013). So, it has been perceived by the agricultural economists that "crop diversification can be one of the most ecologically feasible, cost-effective, and rational ways of reducing uncertainties in agriculture especially among smallholder farmers" (Joshi et al., 2004). It has been argued that the shift of crop mix towards the high valued crops will eventually lead to more income for the farmers if the crops are ensured reasonable market prices as most of these crops are of high yielding varieties. For achieving a sustainable agricultural practices concerning the global climatic changs and for reducing the negative effects, policies should include crop and enterprise diversification, land and water management, and livestock management (Wall and Smith, 2005).

"A proper and scientific crop mixtures are mostly like to work by increasing natural enemies of insect pests, breaking the disease cycles, suppressing weeds and volunteer crop plants thereby creating a dilution effect by reducing resource concentration and modification of the microenvironment within the crop canopy and or making pest and diseases pathogen penetration more difficult" (Lin, 2011; Shoffner and Tooker, 2013).

All of these factors are supply-side factors. Coming to the demand side factors, the first essential is the food habit of people. The food habits of the people should also be changed to create enough marketing potentials for these new crops. The food habits of the people have also been changing gradually due to globalization as there were significant shifts in the diet of the people of low- and middle-income countries toward increased refined carbohydrates added sweeteners, edible oils, and animal-source foods and reduced legumes, other vegetables, and fruits (Popkin, 2015). These are all considered as the commercial cash crops from the farmers' viewpoint and have the potential to generate more revenues for the farmers. So, changing the food habits of the people can also give rise to the demand for diversified cropping patterns.

In the farming sector, diversification can take place either through area amplification or by crop substitution. $\mathrm{Nepal}^{1}$ is located mainly in the Himalayas but also includes parts of Indo-Gangetic Plain. It is a landlocked country that borders China in the north and India in the south, east, and west. The Himalaya, high hills, mid-hills, Siwalik and Terai, are the five main geographic divisions of Nepal. Although agriculture is the prime occupation of the majority of the population ( 83 percent of population relies on agriculture), it is mostly dominated by marginal \& small farms (less than one hectare) and operates at the low economies of scale (Central Bureau of Statistics, 2013). Around $40 \%$ of agricultural households have less than 0.5 hectares and $26 \%$ have between 0.5 and 1.0 hectares. The average size of landholding is 1.3 hectares in lowland and 0.9 hectares in the hilly region. Besides, it is challenging for the farmers with possession of fewer than 0.5 hectares of land to meet the food requirement of a family with the above five members (Rapsomanikis, 2015). The Nepal government has decided to expand "The Prime Minister Agriculture Modernization Project " and grants are decided to provide improved seeds and plants of tea, coffee, cardamom, areca nuts, potato, banana, and lemon and is allocated 4.77 billion to execute this project effectively. The government of Nepal has allocated 33.71 billion for the agricultural sector for the fiscal year (2015-16) which is a $39.29 \%$ increase in agricultural budget from the previous year (MOF, 2018). Similarly, rural poverty can be reduced by increasing yields and enhancing the productivity of agricultural labor (Cervantes-Godoy and Dewbre, 2010). Farmers in Nepal face problems in marketing and commercializing their products due to lack of market facility, lack of transportation, and credit facility. Though most of the farmers in Nepal produce basic staple grains where about $82 \%$ of cultivated land is planted with cereal crops (Nepal Agricultural Research

\footnotetext{
${ }^{1}$ Officially known as Federal Democratic Republic of Nepal
} 
Council, 1995), therehave been steady growths in the share of the commercial cash crops in the crop mix of the country during the last 2-3 decades. For instance, the area under rice cultivation has increased steadily from 1368420 hectares in 1994 to 1549447 hectares in 2006 afterward it has been fluctuating continuously and settled at 1362908 hectares in 2016. In contrast to this, the area under fresh fruits has been rising steadily since the last decades - 12160 hectares in 1995 to 17474 hectares in 2002 and further went up to 27122 in 2017. Similarly, the area under fresh vegetables has been rising very steadily even without any fluctuations in its cultivated area 122012 hectares in 1991 to 229761 hectares in 2009 and finally reached at 289961 hectares in 2016.

There is plenty of literature on the specific issue of crop diversification at all levels of study - local level (using farm-level data), national level, and international level. As the current research does not cover any farm-level data, the review of literature will not consider the crop diversification at the farm level; rather, it will find only the macro level (national and international level) crop diversification.

The south Asian countries are gradually diversifying with some inter-country variation in favor of "high-value commodities, namely, fruits, vegetables, livestock, and fisheries" (Joshi et al, 2003). They have also argued that the diversification process is strongly influenced by price policy, infrastructural development, urbanization, and technological improvements. Agricultural diversification is also contributing to employment opportunities in agriculture and increasing exports. Reforms in developing and strengthening desired institutions through required legal changes would go a long way in boosting agricultural growth through these diversified agricultural practices which in turn will augment the income of small farm holders and promote exports.

The practice of agricultural policy of staple food self-sufficiency being the cornerstone of agricultural policy in most of the developing countries has become increasingly obsolete with the pace of economic growth (Dorjee et al., 2003). In South Asia, the share of cereals in agricultural output has remained unchanged; however, the share of cereals in consumption has declined markedly due to inappropriate government price support policies and associated institutions for cereals in some countries. The main identified factors which are acting as constraints in the process of diversifying agricultural crop mix were the size of markets and price risks, soil suitability and land rights, the availability and quality of irrigation infrastructure, and the availability and cost of labor (Dorjee et al., 2003). This has also been supprted by De (De, 2003) and De and Chattopadhyay (De and Chattopadhyay, 2010) in the context of explaining the increasing importance of irrigation and technology in the phenomenal growth of commerical crops such as potato in the West Bengal province of India.

Due to its climatic conditions and food habits of the Nepalese people, rice is the main dominant crop both in the terai (plains) and hills followed by wheat, maize, and potato. It is true both for irrigated and non-irrigated areas. However, in the mountains of the country, maize and vegetables are taking the dominant crop shares (Sharma, 2020). The Agriculture Perspective Plan (APP) is a 20-year plan on which the whole agricultural strategy of the country lies. The main objectives of APP are to reduce poverty by $35 \%$ over 20 years; and to increase the rate of growth of agricultural GDP from the current low level of $3 \%$ per annum to about $5 \%$, thereby using agriculture as the growth engine for the rest of the economy. The government has established a strategy for implementation of the APP, such as the pocket package strategy, and GO-NGO-Private sector partnership, etc. Pockets of commercially available commodities will be developed and a suitable package of technologies will be provided.

One of the primary objectives of the Agriculture Perspective Plan (APP) is to reduce the poverty level by increasing the growth rate of agricultural GDP of the country and crop diversification has been a significant thrust engine for the long-term plan. Sharma (2020) has also pointed out some significant constraints in terms of policies, infrastructural, and intuitional factors that act as the main bottlenecks for agricultural diversification in Nepal.

Despite several obstacles, there has been a rightward shift in favor of high-value crops between 1995 and 2004 and between 2004 and 2010, respectively (Thapa et al., 2017). They have identified that female-headed households, caste, mother's education, net-buyer status, urban region, remittance, farm size, kitchen garden, improved seeds, telephone, and refrigerator have a positive impact on the agricultural diversification and diversification, in turn, has a positive impact on raising the farmers per capita consumption of the farmers.

Diversification of cropping patterns has also been very crucial from the adaptive viewpoint concerning the climatic change (Bradshaw et al., 2004; Ellen and Barry, 2005; Kishore et al., 2018). 
Furthermore, international trade openness through the liberalization of agricultural trade might have some impact on crop diversification. In fact, during the mid-nineties, the differences between domestic and international prices were significantly high in many developing countries like India which helped to concentrate on 'high value' crops such as fruits and vegetables (Jha et al., 2009). However, there is a great deal of debate about whether liberalized agricultural trade will lead to increased crop diversity (Fraser, 2006). There can be both beneficial and detrimental effects of the trade liberalization on agricultural biological diversity. Non-availability of appropriate data and methodological problems make it further challenging to prescribe robust empirical assessments of the direction of the overall outcome (Secretariat of the Convention on Biological, 2005).

So, the rural household diversification vis-à-vis agricultural crop diversification seems to be an engine for enhancing the farmer's income base as well as can be used as an alternative strategy to cope up with the climatic change. Along with the natural geographical advantages, some economic and institutional factors such as irrigation facilities, technological innovation through the method of cultivation, improved seeds, urbanization, farm size, foreign aid, trade liberalization, better communication, etc. might have essential bearings on diversifying the cropping pattern (Thapa et al., 2017).

Thus, agricultural crop diversification is essentially an outcome of several socio-economic and technological factors which are also interlinked to each other and thereby giving rise to some significant direction to the crop mix of an economy. Also, the direction and strength of the effect of all such factors depend on the level of economic development achieved by the country. Under these backdrops, this paper deals with the behavior of cropping pattern changes in Nepal from 1960 to 2017. The specific objectives of the study are -

(a) To examine the growth of agricultural crop over the different phases of economic and political conditions prevailing in Nepal;

(b) To explore the nature of the changes in the crop diversification or specialization at the macro level; and

(c) To identify the determining economic factors behind the changes in the crop mix of the farming sector of Nepal.

\section{Materials and Methods}

\subsection{Data Source}

The whole study is based on the secondary data for the period $(1961-2017)$ and the data were collected and compiled from the Food and Agricultural Organisation ${ }^{2}$ and Central Bureau of Statistics, Nepal.

\subsection{Growth Decomposition by Kinked Exponential Method}

For measuring the growth performances of the different crops and crop groups in Nepal, the whole period of 57 years has been divided into three sub-periods as sub-period I: 1961 to 1985, sub-period II: 1986 - 2007 and sub-period III: 2008 -2017. Sub-period I is the era of economic development under the policy of economic development through the state-controlled Five Years Plans. The second sub-period was capturing the Nepal economy when the policy of economic liberalization was introduced in the mid-1980s which was accelerated further with the start of the 1990s. Finally, the third sub-period is the mark of abolishing the monarchy and beginning of the journey as a federal republic state.

The simple kinked (double kinked) exponential growth model has been adopted for estimating the growth performance in the three different sub-periods.

Where;

$\mathrm{InQ}_{\mathrm{t}}=\mathrm{a}_{1}+\mathrm{b}_{1}\left(\mathrm{D}_{1} \mathrm{t}+\mathrm{D}_{2} \mathrm{k}_{1}+\mathrm{D}_{3} \mathrm{k}_{1}\right)+\mathrm{b}_{2}\left(\mathrm{D}_{2} \mathrm{t}-\mathrm{D}_{2} \mathrm{k}_{1}-\mathrm{D}_{3} \mathrm{k}_{1}+\mathrm{D}_{3} \mathrm{k}_{2}\right)+\mathrm{b}_{3}\left(\mathrm{D}_{3} \mathrm{t}-\mathrm{D}_{3} \mathrm{k}_{2}\right)+\mathrm{u}_{\mathrm{t}}$

$D_{1}=1$, for thesub-period I

$=0$, otherwise

\footnotetext{
${ }^{2}$ FAOSTAT
} 


$$
\begin{aligned}
D_{2} & =1, \text { for the sub-period II } \\
& =0, \text { otherwise } \\
D_{3} & =1, \text { for the sub-period III } \\
& =0, \text { otherwise }
\end{aligned}
$$

$\mathrm{k}_{1}$ and $\mathrm{k}_{2}$ are the first and second kink (break) points.

In $(\mathrm{Qt})$ is the natural logarithm of the variable $\mathrm{Q}$, and $\mathrm{t}$ denotes the time. The variable $\mathrm{Q}$ will measure the area, yield, and production of major crops (crop-groups) over the period $1961-2017$.

In the above equation $b_{1}, b_{2}$ and $b_{3}$ are the growth rates for the first, second, and third sub-periods respectively. Estimating the trend break equation also tests the significance of the difference between the growth rates in two different sub-periods

$$
\operatorname{InQ} t=a_{1}+b_{1} t+b_{1} *\left(D_{2} t-D_{2} k_{1}-D_{3} k_{1}+D_{3} t\right)+b_{2} *\left(D_{3} t-D_{3} k_{2}\right)+U_{t}
$$

where $b_{1} *$ and $b_{2} *$ are the divergence between the first and second sub-period growth rates and the divergences between the third and second sub-period respectively.

\subsection{Diversification Measures}

For measuring the diversity in the crop mix in an economy, there are quite a few methods viz. Species Richness, Species Evenness, Entropy Index, Gini index, Herfindahl Index, Simpson Index, Shannon's diversity index, etc. The agricultural diversification in Nepal has been measured using both Shanon's index and Herfindahl's index.

Simpson's diversity index is defined as:

$$
D=\sum_{i=1}^{s} p_{i}^{2}
$$

Now D is a measure of dominance, so as D increases, diversity decreases. Thus, Simpson's index is usually considered as its complement 1-D (or sometimes 1/D). Since D takes on values from zero to one and the measure (D) approaches one in the case of a monocropping system, (1-D) provides a measure of diversity which is much less sensitive to a richness in species.

As $0 \leq \mathrm{D} \leq 1$, with values close to zero correspondings to highly diverse or heterogeneous cropping patterns and values close to one corresponding to more homogeneous cropping pattern, it is more pragmatic to change the directional value of the index, taking it as $1-\mathrm{D}$ instead as

$$
\widetilde{D}=1-D=1-\sum_{i=1}^{s} p_{i}^{2}
$$

This quantity is called by statisticians the index of diversity. So, a higher value is indicating greater diversification.

In Economics, virtually the same quantity is called the Hirschman-Herfindahl index (HHI).

Shannon's diversity index, simply the ecologist's name for the communication entropy introduced by Claude Shannon, is given as:

$$
H=-\sum_{i=1}^{s} p_{i} \ln p_{i}
$$

Where $p_{i}$ is the fraction of individuals belonging to the ith species. For a well-sampled population unit, we can estimate this proportion as $p_{i}=n_{i} / N$, where $n_{i}$ is the number of individuals in species i and $\mathrm{N}$ is the total number 

of individuals in the sample. Since by definition, the $p_{i}$ will all be between zero and one, the natural log makes all of the terms of the summation negative, which is why we take the inverse of the sum.

Typical the index values lie between 1.5 and 3.5 in most cases in agricultural crop diversification measures, and the index is rarely greater than 4 . The Shannon index increases as both the richness and the evenness of the sample increase. The incorporation of both components of diversity can be seen as a strength as well as a weakness. It is a strength because it provides a simple, synthetic summary, but it is a weakness because it makes it challenging to compare two cropping patterns that differ significantly in richness. Due to the confounding of richness and evenness in the Shannon index, many biodiversity researchers prefer to stick to two numbers for comparative studies, combining a direct estimate of species richness (the total number of species in the sample unit, S) with some measure of dominance or evenness. The most common dominance measure is the Simpson's index.

\subsection{Determinants of Diversification}

Next, to identify the driving force behind the diversification (or concentration), a multiple linear regression framework has been adopted.

$\mathrm{DI}_{\mathrm{HH}}$ or $\mathrm{DI}_{\mathrm{SH}}=\beta_{0}+\beta_{1} \mathrm{TECH}+\beta_{2}$ INFRA $+\beta_{3}$ POLICY $+\beta_{4}$ DEMAND $+\beta_{5}$ TRADE

The dependent variable is identified in two ways:

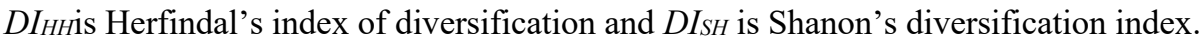

The independent variables are identified as:

TECH stands for technological factors, INFRA portrays all infrastructural variables, POLICY stands for a vector of dummy variables indicating the major policy shift in the economy, DEMAND is demand-side variables and TRADE is a vector for international trade-related variables.

Based on the availability and usability of the data, the following variables were identified:

Fertilizer usage per hectare is taken as technological variables. For infrastructure (INFRA), irrigation coverage (\% of actual cropped area irrigated) as a proxy for physical infrastructure is considered. For DEMAND, the urbanization rate ( $\%$ of urban population to total population) is taken. Finally, for the trade openness (TRADE)(export + import/ gdp) is considered as liberalization of trade policy. The details specification of variables and their expected sign are given in the Table 1 below:

Table 1. Possible determinants of diversification with desired directions of effects

\begin{tabular}{|c|c|c|c|c|}
\hline Drivers & Variables & & Units of measurement & $\begin{array}{l}\text { Expected } \\
\text { sign }\end{array}$ \\
\hline TECH & \multicolumn{2}{|l|}{ Fertilizer usage } & $\begin{array}{l}\text { Tonnes of fertilizers used per hectare } \\
\text { of Gross Cropped Area }\end{array}$ & + \\
\hline INFRA & \multicolumn{2}{|l|}{ Irrigation coverage } & $\begin{array}{l}\text { Proportion irrigated are to the } \\
\text { gross cropped area }(\%)\end{array}$ & + \\
\hline DEMAND & \multicolumn{2}{|l|}{ Urbanization } & $\begin{array}{l}\text { The proportion of the urban population } \\
\text { to the total population }(\%)\end{array}$ & + \\
\hline TRADE & \multicolumn{2}{|l|}{ Trade openness } & $\begin{array}{l}\text { Share of export and import to the total } \\
\text { GDP }(\%)\end{array}$ & $+/-$ \\
\hline \multirow[t]{2}{*}{ POLICY } & $\begin{array}{l}\text { Time dummies } \\
\text { Time dummyl }\end{array}$ & $\begin{array}{l}=1, \text { for } 2 \text { nd sub-period } \\
=0 \text {, otherwise }\end{array}$ & $\begin{array}{l}\text { The policy shift from a controlled } \\
\text { economy to a global economy and of } \\
\text { abolishing the monarchy for starting }\end{array}$ & $+/-$ \\
\hline & Time dummy 2 & $\begin{array}{l}=1, \text { for } 3 \text { nd sub-period } \\
=0, \text { otherwise }\end{array}$ & journey as a federal republic state. & \\
\hline
\end{tabular}

Source: Author's own

As the value of Herfindal's index lies between 0 and 1, it is not wise to use the Ordinary Least Squares Method (OLSM) to estimate the parameters of the model. The use of OLSM will produce inefficient estimates, especially when the Herfindahl Index value becomes clustered around the mean level meaning very fewer fluctuations in diversification over the years. Instead of that, beta regression has been used to estimate the parameters of the model. However, there is no such harm in applying the OLSM to estimate the parameters of the model, when the extent of diversification has been measured by Shanon's method as the index value will vary to a more considerable 
extent (not restricted between 0 and 1). Thus, the same mathematical model has been estimated twice - one by beta regression method and the other OLSM.

\section{Results and Discussion}

\subsection{Trends in crop area of major crops}

The focus has been given on the area share of high-value crops to the total cropped area as an indicator of crop diversity given the importance of high-value crops and emphasis placed by the Nepal government on promoting high value and commercial crops. Table 2 illustrates the percentage of the area allocated to different crops in 1961, 1981, 1991, 2001, and 2017.

Table 2. Area shares of major crops over the years

\begin{tabular}{llllll}
\hline \multirow{2}{*}{ Crops/Crop Groups } & \multicolumn{5}{c}{ Percentage Share in Total Agricultural Land } \\
& 1961 & 1981 & 1991 & 2001 & 2017 \\
\hline Rice & 51.31 & 45.10 & 34.78 & 34.20 & 30.35 \\
Maize & 20.37 & 16.54 & 18.58 & 18.59 & 17.60 \\
Wheat & 5.18 & 13.63 & 14.60 & 14.45 & 14.39 \\
Total pulses & 8.16 & 9.36 & 6.73 & 6.44 & 6.48 \\
Food grain crops & 89.04 & 89.81 & 80.30 & 80.17 & 74.73 \\
Oil crops & 6.56 & 5.09 & 8.89 & 8.78 & 7.98 \\
Root crops & 2.31 & 2.20 & 2.79 & 3.41 & 4.48 \\
Fibre Crops & 1.41 & 1.81 & 0.39 & 0.28 & 0.17 \\
Vegetable Crops & $\mathrm{NA}$ & $\mathrm{NA}$ & $\mathrm{NA}$ & 0.13 & 0.38 \\
Sugarcane & 0.33 & 0.83 & 0.81 & 1.34 & 1.40 \\
\hline
\end{tabular}

Source: Author's own

Major cereals (rice, maize and wheat) and pulses occupied a major sharein the total agricultural land of the country. In 1961, these three top crops together accounted for $76.86 \%$ of the entire agricultural land of the country while in 2001, the share decreased to $67.24 \%$ in 2001 and $62.34 \%$ in 2017 . The relative area under rice cultivation has been continuously decreased over the period 2001 to 2016, the areas under the other major foodgrain crop viz. maize has been showing a marginal fall in its relative area share while wheat has a sharp increase in relative area gain from $5.18 \%$ in 1961 to $13.63 \%$ in 1981 and thereafter remained stagnant at that level for the subsequent time points.

The cropping pattern was found to be dominated mostly by the food grain crops. However, some transition has also been observed first in 1991 and second in 2017 when the food grain crops have lost their acreage to other nonfood grain crops. For instance, the area under the root crops and vegetables (high-value crops) have been found to gain their area shares in the total agricultural land significantly at the end of the study period (2017). This area expansion under food grain crops is quite expected to feed the 2.93 crores people of Nepal. But there has been some intercrop substitution as the area under rice being taken away by other food grain crops (mainly wheat) and other non-food grain crops. At the same time, it is also true that the choice of the Nepalese has also been widened especially during the last decade as the area allocation under vegetable crops and root crops have been almost doubled during the same period. Also, the country has been producing and exporting tea recently. Before 2000, the tea industry was a Government monopoly and Nepal's tea exports accounted for only about $100-150$ tons per annum. However, due to the liberalization adopted nearly a decade ago, Nepal's tea industry witnessed an exponential rise in tea exports, accounting for almost 4,000 - 5,000 tons per annum. At present, Nepal produces 24.653 million tonnes of tea per annum on an area of 28.522 hectares.

The following Figure 1 shows the area allocation of different food grain crops in Nepal during the period 1961 to 2017. Rice, the main food grain crop, has increased steadily up to 1990 and afterward it shows a declining trend until 1995. Though it started regaining its position during the late nineties, overall, it was showing the absolute decline in the area in the recent past. The other two food grain crops viz. wheat and maize have shown a continuous increase in the area of cultivation over the years. However, their relative shares are not so high as compared to rice. The area under pulses which is considered to be the primary source of protein especially for poor economies like Nepal remained stagnant for many years. It has been a significant concern as the percentage of children under 

five years of age who are stunted (\%) is very high in Nepal $(57.1 \%, 49.3 \%$, and $35.8 \%$ respectively in 2001 , 2014 and 2016, FAO). Also, due to this, the import of pulses both in value and quantity terms is quite alarming (Figure 2).

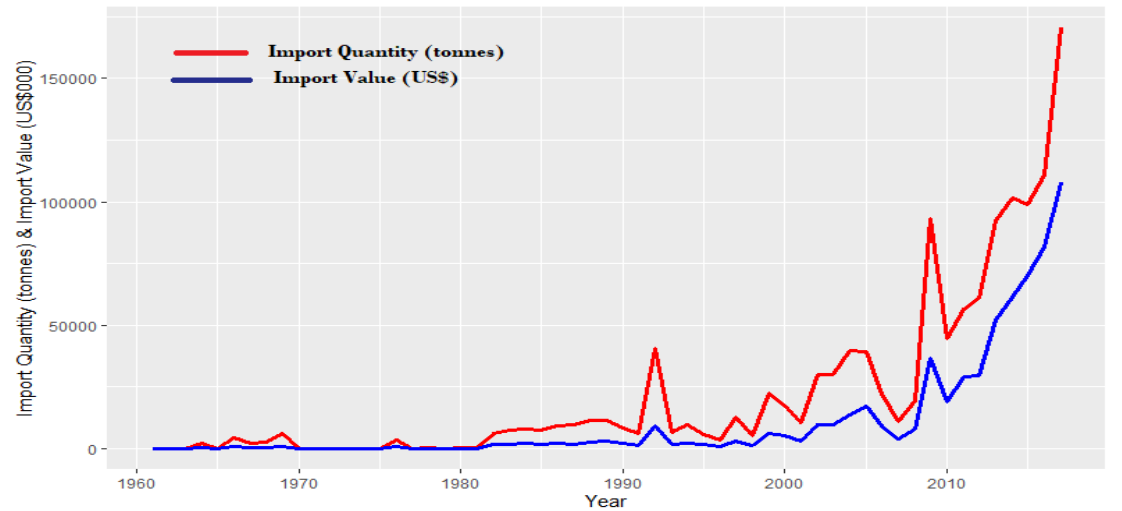

Figure 1. Import of pulses both in quantity and values terms over the years (Source: Author's own)

Coming to the area allocations under the non-foodgrain crops, almost all the major non-food grain crops (except the fiber crops) have witnessed steady growth over the years. The oil crops and tea have started to grow since the mid-eighties and nineties, respectively. Thus, it has been observed that the relative area allocations of the food grain crops have either remained stagnant or started decreasing while the area under most of the non-food grain crops has shown a huge increasing trend since the last two-three decades.

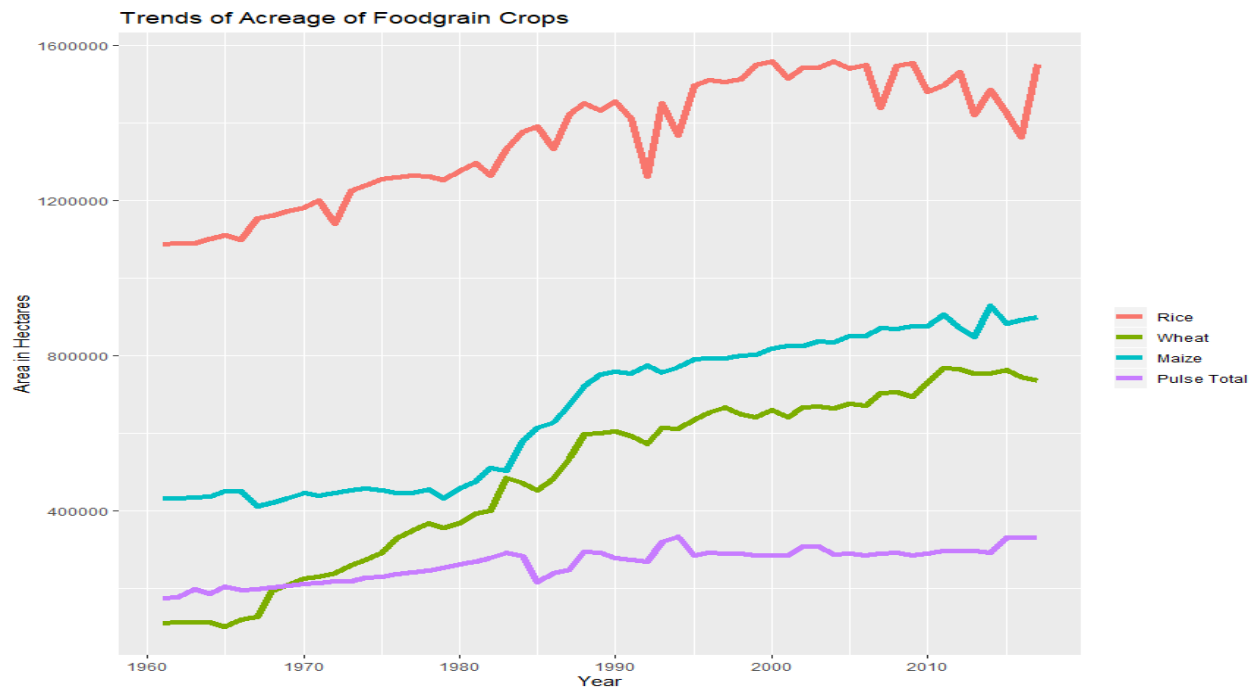

Figure 2. Trends in Foodgrain Crops in Nepal (Source: Author's own)

\subsection{Decomposition of Production Growth of Major Crops into Area and Yields Components}

Further, these changes in the area allocations of different competitive crops along with their yield rates might have some significant impact on the production of these crops. To examine the effect of both area and yield growths on the production growth of the major crops, the simple individual crops decomposition scheme has been applied by dividing the whole period of 1961 - 2017 into three different sub-periods, as mentioned in the methodological section. The exponential growth rates of production, area, and yield of the major crop/crop groups have also been calculated for all the sub-periods along with their trend break differences and reported in Tables 3, 4, and 5 . 
JOTAF/ Journal of Tekirdag Agricultural Faculty, 2021, 18(4)

\begin{tabular}{|c|c|c|c|c|c|c|c|}
\hline \multicolumn{8}{|c|}{ Table 3. Exponential Growth Rates of Production Major Crops in different sub-periods } \\
\hline Crops & $\begin{array}{l}\text { Sub-period } \\
\text { I }\end{array}$ & $\begin{array}{l}\text { Sub-period } \\
\text { II }\end{array}$ & $\begin{array}{l}\text { Sub- } \\
\text { period III }\end{array}$ & $\begin{array}{l}\text { First trend } \\
\text { difference }\end{array}$ & $\begin{array}{l}\text { Second trend } \\
\text { difference }\end{array}$ & R-squared & $\begin{array}{l}\text { D.W. } \\
\text { statistic }\end{array}$ \\
\hline Rice & $\begin{array}{l}1.21 \\
(5.834)\end{array}$ & $\begin{array}{l}2.32 \\
(10.418)\end{array}$ & $\begin{array}{l}0.67 \\
(0.872)\end{array}$ & $\begin{array}{l}1.11 \\
(2.87)\end{array}$ & $\begin{array}{l}-1.65 \\
(-1.797)\end{array}$ & 0.89 & 1.81 \\
\hline Wheat & $\begin{array}{l}6.99 \\
(34.914)\end{array}$ & $\begin{array}{l}3.70 \\
(17.274)\end{array}$ & $\begin{array}{l}2.56 \\
(3.445)\end{array}$ & $\begin{array}{l}-2.28 \\
(-8.852)\end{array}$ & $\begin{array}{l}-1.14 \\
(-1.296)\end{array}$ & 0.98 & 1.38 \\
\hline Maize & $\begin{array}{l}0.32 \\
(0.71)\end{array}$ & $\begin{array}{l}3.70 \\
(7.491)\end{array}$ & $\begin{array}{l}1.91 \\
(1.426)\end{array}$ & $\begin{array}{l}3.38 \\
(4.059)\end{array}$ & $\begin{array}{l}-1.79 \\
(-1.084)\end{array}$ & 0.56 & 2.37 \\
\hline Pulses & $\begin{array}{l}2.20^{*} \\
(11.293)\end{array}$ & $\begin{array}{l}2.22^{*} \\
(10.497)\end{array}$ & $\begin{array}{l}4.17^{*} \\
(6.145)\end{array}$ & $\begin{array}{l}2.697 \mathrm{e}-04 \\
(0.074)\end{array}$ & $\begin{array}{l}1.944 \mathrm{e}-02^{* *} \\
(2.381)\end{array}$ & 0.98 & 1.94 \\
\hline Oilseeds & $\begin{array}{l}3.17^{*} \\
(3.381)\end{array}$ & $\begin{array}{l}3.65^{*} \\
(3.45)\end{array}$ & $\begin{array}{l}2.16^{*} \\
(3.78)\end{array}$ & $\begin{array}{l}0.48 \\
(0.785)\end{array}$ & $\begin{array}{l}-1.48 \\
(-0.34)\end{array}$ & 0.44 & 1.95 \\
\hline $\begin{array}{l}\text { Roots \& } \\
\text { Tubers }\end{array}$ & $\begin{array}{l}2.72^{*} \\
(6.567)\end{array}$ & $\begin{array}{l}7.01^{*} \\
(14.841)\end{array}$ & $\begin{array}{l}2.59^{*} \\
(1.891)\end{array}$ & $\begin{array}{l}4.29^{*} \\
(5.347)\end{array}$ & $\begin{array}{l}-4.43^{*} \\
(-2.645)\end{array}$ & 0.98 & 2.06 \\
\hline Fiber crops & $\begin{array}{l}-0.80 \\
(-0.463)\end{array}$ & $\begin{array}{l}-4.25^{* *} \\
(-2.181)\end{array}$ & $\begin{array}{l}1.47 \\
(0.213)\end{array}$ & $\begin{array}{l}-3.45 \\
(-1.062)\end{array}$ & $\begin{array}{l}5.73 \\
(0.714)\end{array}$ & 0.87 & 1.99 \\
\hline Vegetables & $\begin{array}{l}8.85^{*} \\
(32.884)\end{array}$ & $\begin{array}{l}5.25^{*} \\
(17.749)\end{array}$ & $\begin{array}{l}5.30^{*} \\
(5.928)\end{array}$ & $\begin{array}{l}-3.60^{*} \\
(-7.128)\end{array}$ & $\begin{array}{l}0.05 \\
(0.043)\end{array}$ & 0.98 & 2.15 \\
\hline Sugarcane & $\begin{array}{l}7.28^{*} \\
(13.487)\end{array}$ & $\begin{array}{l}6.83^{*} \\
(11.597)\end{array}$ & $\begin{array}{l}0.77 \\
(0.414)\end{array}$ & $\begin{array}{l}-0.44 \\
(0.438)\end{array}$ & $\begin{array}{l}-6.07^{*} \\
(-2.709)\end{array}$ & 0.96 & 2.11 \\
\hline Tea & $\begin{array}{l}10.51^{*} \\
(6.644)\end{array}$ & $\begin{array}{l}12.54^{*} \\
(15.127) \\
\end{array}$ & $\begin{array}{l}5.41^{* *} \\
(2.555)\end{array}$ & $\begin{array}{l}2.03 \\
(0.944) \\
\end{array}$ & $\begin{array}{l}-7.13^{* *} \\
(-2.694) \\
\end{array}$ & 0.94 & 1.93 \\
\hline
\end{tabular}

Source: Author's estimation * means significant at $1 \%$ level of significance $\& * *$ means significant at $5 \%$ level of significance.

Table 4. Exponential Growth Rates of Area Under Major Crops

\begin{tabular}{|c|c|c|c|c|c|c|c|}
\hline Crops & $\begin{array}{l}\text { Sub-period } \\
\text { I }\end{array}$ & $\begin{array}{l}\text { Sub-period } \\
\text { II }\end{array}$ & $\begin{array}{l}\text { Sub-period } \\
\text { III }\end{array}$ & $\begin{array}{l}\text { First trend } \\
\text { difference }\end{array}$ & $\begin{array}{ll}\begin{array}{l}\text { Second } \\
\text { difference }\end{array} & \text { trend } \\
\end{array}$ & $\begin{array}{l}\text { R- } \\
\text { squared }\end{array}$ & $\begin{array}{l}\text { D.W. } \\
\text { statistic }\end{array}$ \\
\hline Rice & $\begin{array}{l}1.02^{*} \\
(14.018)\end{array}$ & $\begin{array}{l}0.56^{*} \\
(7.164)\end{array}$ & $\begin{array}{l}-1.01^{*} \\
(-3.747)\end{array}$ & $\begin{array}{l}-0.46^{*} \\
(-3.422)\end{array}$ & $\begin{array}{l}-1.57^{*} \\
(-4.896)\end{array}$ & 0.91 & 1.82 \\
\hline Wheat & $\begin{array}{l}6.66^{*} \\
(16.281)\end{array}$ & $\begin{array}{l}1.14 * * \\
(2.503)\end{array}$ & $\begin{array}{l}0.50 \\
(0.40)\end{array}$ & $\begin{array}{l}-5.52^{*} \\
(-7.182)\end{array}$ & $\begin{array}{l}-0.64 \\
(-0.411)\end{array}$ & 0.97 & 1.72 \\
\hline Maize & $\begin{array}{l}1.56^{*} \\
(3.163)\end{array}$ & $\begin{array}{l}1.68^{*} \\
(3.083)\end{array}$ & $\begin{array}{l}0.31 \\
(0.298)\end{array}$ & $\begin{array}{l}0.12 \\
(0.139)\end{array}$ & $\begin{array}{l}-1.37 \\
(-1.041)\end{array}$ & 0.98 & 1.99 \\
\hline Pulses & $\begin{array}{l}1.78 * \\
(7.951)\end{array}$ & $\begin{array}{l}0.13 \\
(0.527)\end{array}$ & $\begin{array}{l}2.38^{*} \\
(3.072)\end{array}$ & $\begin{array}{l}-1.65^{*} \\
(-3.944)\end{array}$ & $\begin{array}{l}2.25 * * \\
(2.41)\end{array}$ & 0.98 & 1.73 \\
\hline Oilseeds & $\begin{array}{l}3.24 * \\
(2.834)\end{array}$ & $\begin{array}{l}2.87 * * \\
(2.244)\end{array}$ & $\begin{array}{l}-6.28^{* *} \\
(-2.064)\end{array}$ & $\begin{array}{l}-0.36 \\
(-0.173)\end{array}$ & $\begin{array}{l}-9.15 * * \\
(-2.392)\end{array}$ & 0.95 & 1.35 \\
\hline $\begin{array}{l}\text { Roots } \quad \& \\
\text { Tubers }\end{array}$ & $\begin{array}{l}2.64^{*} \\
(8.144)\end{array}$ & $\begin{array}{l}3.58^{*} \\
(9.896)\end{array}$ & $\begin{array}{l}2.64 * * \\
(2.359)\end{array}$ & $\begin{array}{l}0.94 \\
(1.545)\end{array}$ & $\begin{array}{l}-0.94 \\
(-0.697)\end{array}$ & 0.98 & 2.04 \\
\hline Fiber crops & $\begin{array}{l}-0.12 \\
(-0.04)\end{array}$ & $\begin{array}{l}-9.78^{*} \\
(-2.997)\end{array}$ & $\begin{array}{l}51.79 * \\
(7.051)\end{array}$ & $\begin{array}{l}-9.66 * * * \\
(-1.754)\end{array}$ & $\begin{array}{l}61.58^{*} \\
(6.706)\end{array}$ & 0.77 & 1.42 \\
\hline Vegetables & $\begin{array}{l}8.10^{*} \\
(13.219)\end{array}$ & $\begin{array}{l}3.66^{*} \\
(5.49)\end{array}$ & $\begin{array}{l}-4.22 * * * \\
(-1.974)\end{array}$ & $\begin{array}{l}4.44^{*} \\
(-3.876)\end{array}$ & $\begin{array}{l}-7.89^{*} \\
(-3.063)\end{array}$ & 0.90 & 1.35 \\
\hline Sugarcane & $\begin{array}{l}5.26^{*} \\
(11.363)\end{array}$ & $\begin{array}{l}4.36^{*} \\
(8.694)\end{array}$ & $\begin{array}{l}-4.50 * * \\
(-2.711)\end{array}$ & $\begin{array}{l}-0.91 \\
(-1.05)\end{array}$ & $\begin{array}{l}-8.86^{*} \\
(-4.459)\end{array}$ & 0.90 & 1.68 \\
\hline Tea & $\begin{array}{l}10.08 \\
(1.12)\end{array}$ & $\begin{array}{l}13.39^{*} \\
(3.004)\end{array}$ & $\begin{array}{l}38.54^{*} \\
(3.118)\end{array}$ & $\begin{array}{l}3.41 \\
(0.281)\end{array}$ & $\begin{array}{l}25.06 \\
(1.639)\end{array}$ & 0.55 & 1.29 \\
\hline
\end{tabular}

Source: Author's estimation

* means significant at $1 \%$ level of significance $\& * *$ means significant at $5 \%$ level of significance.

The growth estimates of the area, production and yield of major crops (crop-groups) show that the production growth of the most the crops (rice, wheat, maize, oilseeds, Roots \& Tubers, sugarcane) have declined during the third sub-period as compared to the previous two sub-periods. Only pulses and fiber crop production growth have improved significantly during the third sub-period. For these two crops, the area expansion has been the main contributing factor for the improved growth rates during the third sub-period. As many as four crops (crop-groups) viz. rice, oilseeds, sugarcane, and vegetables, have shown negative growth in their area in the third sub-period. In terms of cash crops, only tea has emerged in a big way in recent times in Nepal with modest rates of growth in area expansion in all three sub-periods. The yield growth of tea was also impressive during the third sub-period compared to the other two. Among other crops, pulses and maize have shown some signs of improvement in their respective yield growth rates. 
Table 5. Exponential Growth Rates of Yields of Major Crops

\begin{tabular}{|c|c|c|c|c|c|c|c|}
\hline Crops & $\begin{array}{l}\text { Sub-period } \\
\text { I }\end{array}$ & Sub-period II & Sub-period III & $\begin{array}{l}\text { First trend } \\
\text { difference }\end{array}$ & $\begin{array}{l}\text { Second trend } \\
\text { difference }\end{array}$ & R-squared & $\begin{array}{l}\text { D.W. } \\
\text { statistic }\end{array}$ \\
\hline Rice & $\begin{array}{l}0.20 \\
(1.256)\end{array}$ & $\begin{array}{l}1.77 * \\
(10.507)\end{array}$ & $\begin{array}{l}1.68 * \\
(2.89)\end{array}$ & $\begin{array}{l}1.57 * \\
(5.391)\end{array}$ & $\begin{array}{l}-0.08 \\
(-0.119)\end{array}$ & 0.87 & 1.73 \\
\hline Wheat & $\begin{array}{l}0.14 \\
(0.527) \\
-1.42 *\end{array}$ & $\begin{array}{l}2.71 * \\
(9.3)\end{array}$ & $\begin{array}{l}1.69 * * * \\
(.821)\end{array}$ & $\begin{array}{l}2.57 * \\
(5.142)\end{array}$ & $\begin{array}{l}-1.02 \\
(-0.916)\end{array}$ & 0.96 & 1.95 \\
\hline Maize & $\begin{array}{l}-1.4 L^{*} \\
(-14.848) \\
0.44 *\end{array}$ & $\begin{array}{l}1.74 * \\
(16.967)\end{array}$ & $\begin{array}{l}2.46^{*} \\
(6.918)\end{array}$ & $\begin{array}{l}3.16^{*} \\
(17.806)\end{array}$ & $\begin{array}{l}0.72 * * * \\
(1.704)\end{array}$ & 0.96 & 1.70 \\
\hline Pulses & $\begin{array}{l}0.44^{*} \\
(3.399) \\
7.92 \mathrm{e}-06\end{array}$ & $\begin{array}{l}2.00 * \\
(14.238)\end{array}$ & $\begin{array}{l}3.04 * \\
(6.665)\end{array}$ & $\begin{array}{l}1.56^{*} \\
(6.466)\end{array}$ & $\begin{array}{l}1.04 * * * \\
(1.892)\end{array}$ & 0.98 & 2.05 \\
\hline Oilseeds & $\begin{array}{l}7.92 \mathrm{e}-06 \\
(0.003) \\
8.896 \mathrm{e}-04\end{array}$ & $\begin{array}{l}9.04 \mathrm{e}-03 * \\
(3.374)\end{array}$ & $\begin{array}{l}3.09 \mathrm{e}-02 * * \\
(2.374)\end{array}$ & $\begin{array}{l}9.03 \mathrm{e}-03 * * * \\
(1.991)\end{array}$ & $\begin{array}{l}2.185 \mathrm{e}-02 \\
(1.498)\end{array}$ & 0.96 & 2.02 \\
\hline $\begin{array}{l}\text { Roots \& } \\
\text { Tubers }\end{array}$ & $\begin{array}{l}8.8900-04 \\
(0.404)\end{array}$ & $\begin{array}{l}3.366 \mathrm{e}-02 \\
(13.907)\end{array}$ & $\begin{array}{l}4.34 \mathrm{e}-03 \\
(0.591)\end{array}$ & $\begin{array}{l}3.27 \\
(7.934)\end{array}$ & $\begin{array}{l}-2.93 \\
(-3.29)\end{array}$ & 0.98 & 1.82 \\
\hline 1uoers & 0.12 & 0.87 & -0.70 & 0.75 & -1.57 & & \\
\hline $\begin{array}{l}\text { Fiber crops } \\
\text { Vegetables }\end{array}$ & $\begin{array}{l}(0.238) \\
0.61 *\end{array}$ & $\begin{array}{l}(1.515) \\
2.14^{*}\end{array}$ & $\begin{array}{l}(-0.294) \\
1.73^{*}\end{array}$ & $\begin{array}{l}(0.778) \\
1.53 *\end{array}$ & $\begin{array}{l}(-0.577) \\
-0.41\end{array}$ & 0.96 & 2.14 \\
\hline o grtadies & $(5.483)$ & $\begin{array}{l}(17.499) \\
283 *\end{array}$ & $\begin{array}{l}(4.825) \\
081\end{array}$ & $\begin{array}{l}(7.37) \\
136\end{array}$ & $\begin{array}{l}(-0.944) \\
-203\end{array}$ & 0.98 & 1.97 \\
\hline Sugarcane & $\begin{array}{l}1.47 * * \\
(2.242)\end{array}$ & $(3.86)$ & $(0.448)$ & $(1.11)$ & $(-0.897)$ & 0.98 & 2.04 \\
\hline Tea & $\begin{array}{l}1.54 \\
(0.395) \\
\end{array}$ & $\begin{array}{l}-3.74 * * * \\
(-1.878)\end{array}$ & $\begin{array}{l}2.37 \\
(0.449)\end{array}$ & $\begin{array}{l}-5.27 \\
(-1.00)\end{array}$ & $\begin{array}{l}6.11 \\
(0.93)\end{array}$ & 0.80 & 1.81 \\
\hline
\end{tabular}

Source: Author's estimation * means significant at $1 \%$ level of significance $\& * *$ means significant at $5 \%$ level of significance.

Thus, it is seen that the over the years some crop substation has taken place in the farming sector of the country. Food grain crops (rice, wheat, maize, etc.) are being replaced by the commercial cash crops such as vegetables, fiber crops, vegetables, and plantation crops (tea) (Figure 3). Among the food grain crops, only pulses have shown improvement in the growth rates of production and area expansion is the main contributory factor. It is a good sign for the economy as a whole as pulses are relatively cheap sources of protein for the people of Nepal.
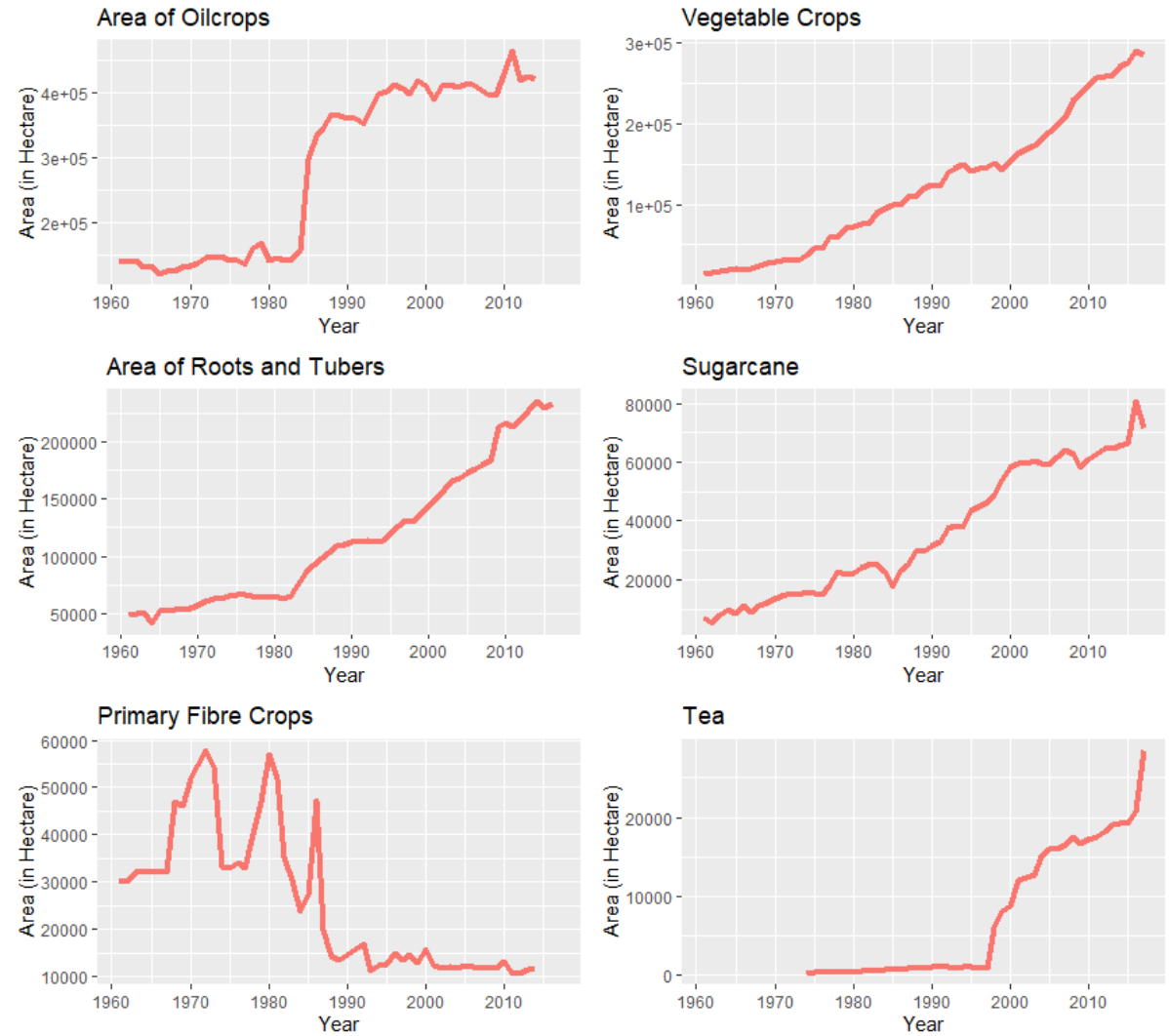

Figure 1. Area Growth of Different Crop in Nepal (Source: Author's calculation based on FAO data) 


\subsection{Changes in Crop Mix Pattern and its determinants}

Although the main focus was on the share of high-value crops in the total agricultural land, as an indicator of agricultural diversity, the Hirshman-Herfindahl index (HHI) and Shannon index have been computed to assess the extent of crop diversification in Nepal. Both the index showing an increasing trend over the years indicates that crop diversity has increased in the Nepalese farming pattern (Figure 4).
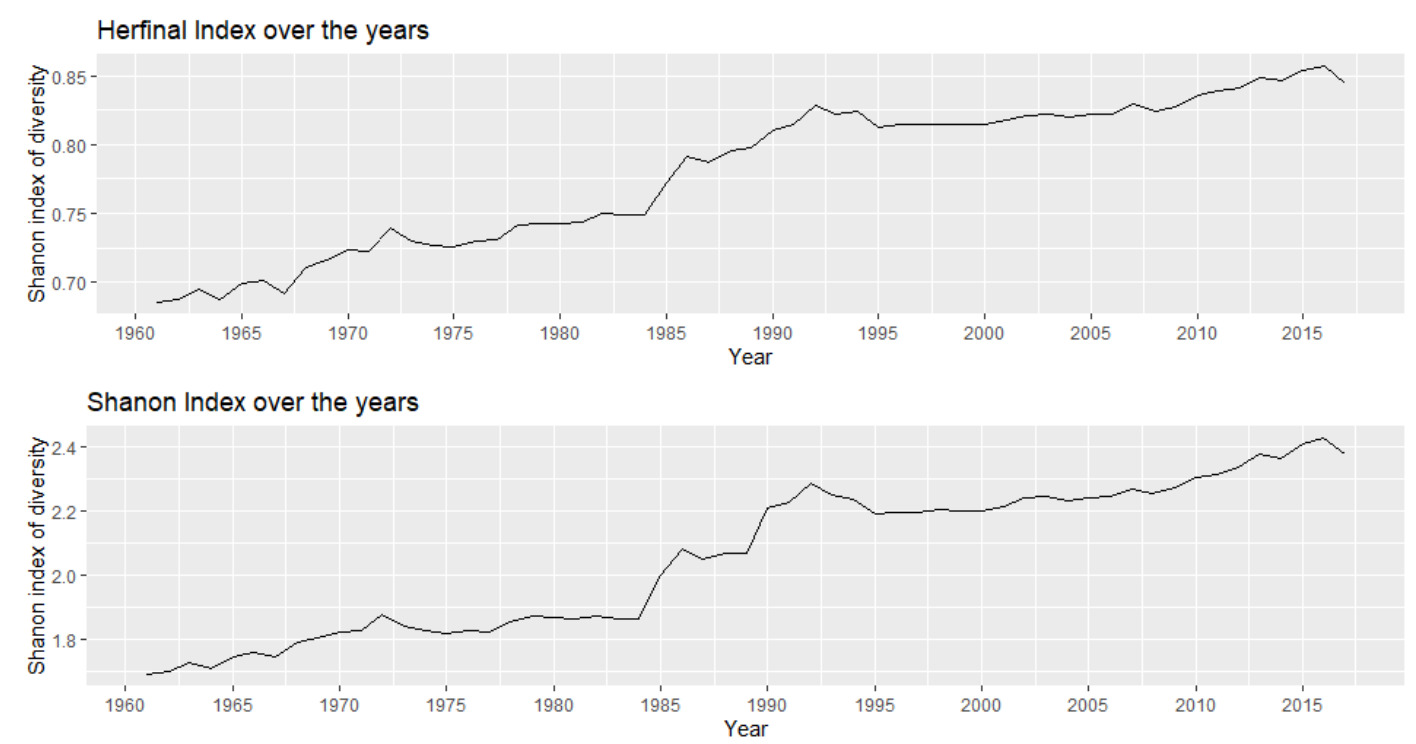

Figure 2.Crop Diversification Indices over the years (Source: Author's estimate based)

It is evident that diversity has increased with more significant momentum during the decade of the eighties as compared to the earlier period and it seems to be stagnant in the recent past. It can be a cause of concern both from the economic and environmental points of view. To find out the drivers of crop diversification, both the beta regression (with Hirshman-Herfindahl index as dependent variable) and normal ordinary least squares estimation (with Shanon index as dependent variable) were used with the same set of independent variables. The results are displayed in the following Table 6.

Table 6. Drivers of Crop Diversification in Nepal

\begin{tabular}{|c|c|c|}
\hline \multirow{2}{*}{ Method of Estimation } & $\begin{array}{l}\text { Model 1: Shanon Index of diversity as } \\
\text { the dependent variable }\end{array}$ & $\begin{array}{l}\text { Model 2: Herfindal Index of diversity } \\
\text { as the dependent variable }\end{array}$ \\
\hline & Ordinary Least Squares Regression & Beta Regression \\
\hline Independent Variable & Coefficient & Coefficient \\
\hline Constant & $\begin{array}{l}0.17176^{*} \\
(0.030680)\end{array}$ & $\begin{array}{l}0.8474^{*} \\
(0.02858)\end{array}$ \\
\hline Trade openness & $\begin{array}{l}-0.0032879^{*} \\
(0.0014910)\end{array}$ & $\begin{array}{l}-0.004933^{*} \\
(0.001738)\end{array}$ \\
\hline Irrigation rate & $\begin{array}{l}0.0094354^{*} \\
(0.0039979)\end{array}$ & $\begin{array}{l}0.01972^{*} \\
(0.003654)\end{array}$ \\
\hline Urban population & $\begin{array}{l}0.019759^{*} \\
(0.0073859)\end{array}$ & $\begin{array}{l}0.01532^{* *} \\
(0.007065)\end{array}$ \\
\hline Fertilizer & $\begin{array}{l}0.000068378^{*} \\
(0.000017005)\end{array}$ & $\begin{array}{l}0.00009416^{*} \\
(0.00002863)\end{array}$ \\
\hline Time dummy 1 & $\begin{array}{l}0.12262^{*} \\
(0.049264)\end{array}$ & $\begin{array}{l}0.1285^{*} \\
(0.02895)\end{array}$ \\
\hline Time dummy 2 & $\begin{array}{l}0.073163^{*} \\
(0.083949)\end{array}$ & $\begin{array}{l}0.08085 \\
(0.05 .05)\end{array}$ \\
\hline Additional Model fit criteria & $\begin{array}{l}\text { Adj. R squared: } 0.959 \\
\text { F - stat : } 221.691\end{array}$ & $\begin{array}{l}\text { Log-likelihood: } 188.1 \\
\text { Pseudo R-squared: } 0.9715\end{array}$ \\
\hline
\end{tabular}

Source: Author's estimation *(All standard errors are heteroscedasticity - autocorrelation consistent) 
Based on the availability of the data for the whole study period as well as the usability of the data, it allows us to include only five variables in the model. In both the model estimations, four out of five variables appear to be statistically significant.

Trade openness is giving a negative impact on the diversification process. The reduction in the trade barriers (or trade openness) will leave the producers to choose the particular basket of crops from a wide variety of crops where they have an advantage in production and hence they can enjoy the export potentials. The export profile of Nepal is also suggesting the same. In 2017, at the 2-digit Harmonized Tariff System code level, Coffee, tea, and spices accounted for or \$US47.6 million which is $6.4 \%$ of the total export value. Non-alcoholic drinks excluding water, juices or milk constitute $5.9 \%$, followed by nutmeg, mace and cardamoms $(5 \%)$, food industry waste and animal fodder accounted for another \$US32.6 million (4.4\%). So, the more the trade openness, the more the chance to concentrate on particular crops where the country has an advantage over others in terms of export potential.

Expansion of more cropped area under irrigation coverage will lead to more diversified agricultural practices which are quite common. Irrigation is the most crucial input of agriculture as it allows the farmers to grow crops based on their requirements and market demand as well. Provision of sustained irrigation facilities has been very crucial for the Nepal agriculture as most of the cultivated area remain unirrigated as only $28 \%$ of the total agricultural land (4.21 million ha) is irrigated (The World Bank, 2020). The provision of sustained irrigation has been the significant difficulties in boosting the agriculture production of the country for a long time. The water use efficiency and agricultural productivity remained low in Nepal as most of the irrigation systems are fed by medium or small rivers, which almost entirely dependent on the rain. The climatic changes have made this more difficult.

Urbanization is putting a significant positive effect on the diversification of cropping pattern. That, as the demography of population changes from rural to urban areas, the demand for food baskets are also going to change. Instead of staple food crops, people demand more verities of crops such as fruits and vegetables which in turn gives rise to diversify the crop mix of the economy.

More usage of fertilizer can be considered as the proxy of better farming techniques and practices. Usually, the high yielding varieties of crops require more usage of fertilizer, secured water supply, and improved farming practices. As the data on these variables are not available for most of the year, fertilizer usage has been taken and it is seen that it has a significant positive effect on crop diversification.

Finally, the time dummy has been taken to see the impact of significant policy reforms that have been implemented extensively during the early nineties for speedy integration of Nepal with the global economy and the shift from kingdom monarchy to a federal republic. Though the initial impact of these reforms on trade and economic growth has not been very impressive, in the long-run, it resulted in a significant positive effect on the agricultural sector as far as the crop diversification is concerned. It has also been seen in the growth analysis of area, production, and yield of major crops of the economy. The second period (period of economic reforms) was the most impressive compared to the first and third sub-period. However, the rising inequality and overall weak infrastructural status of the economy remained as the main obstacles in terms of achieving sustained growth of the agricultural economy and cropping pattern of the farming sector, and in the subsequent period, the impact of time dummy has become statistically insignificant.

\section{Conclusions}

As far as growth analysis of different crops in Nepal, it has been seen that the second sub-period was the most impressive as the growth rates of most of the crops were high compared to the other two sub-periods. The growth rates of many major crops have shown a significant declining trend in the third sub-period. The main reason for this slowing down of major crops (rice, oilseeds, sugarcane, and vegetables) production growth rates was the decline in the area growth rates. However, the positive changes have been observed in terms of growth of pulses, fiber, and tea as their area growth rates have significantly improved during the third sub-period. In general, it has been observed some yield for most of the crops (except pulses, maize, and tea) yield growth rates were not very impressive. That, there has been a rising trend of diversification in the cropping pattern of Nepal agriculture. This trend has been started since the mid-eighties and continued to grow at a significantly high pace until the midnineties. After which the pace has been slowed down relatively. Further, though there is an indication of diversification of cropping pattern, still the food grain crops remain the dominant crop groups in the crop mix of the farmers of Nepal. 
The regression analysis confirms that irrigation coverage and better farming technology, which was proxied by fertilizer usage in agriculture, are helping significantly in a positive direction on diversifying the cropping pattern of Nepal agriculture. Urbanization leads to diversified food preference for the people and so have a favorable implication for crop diversification in Nepal. However, trade openness exerts negative impacts on cropping pattern diversification. It indicates that Nepal has a competitive export advantage only a few selected crops and these crops will be getting preference from the farmers' crop selection on account of better export value and higher income potential. So, the more the trade openness, the more the crop mix is biased towards particular crops where the country has an advantage over others in terms of export potential. It calls for the immediate attention of the policymakers to increase the comparative cost advantage of the other crops so that the diversification of the crop mix is well maintained even in the wake of globalization. For instance, the tea production has been increasing in the eastern to central and western part of country as this part enjoys plenty of rainfall throughout the year and have suitable climatic conditions. Similar, type of crops has to be identified where farmers can enjoy the natural advantage of growing the crops and export at a competitive price in the international markets. It is also crucial from a sustainable environmental viewpoint. The provision of irrigation coverage and adoption of modern farming techniques will undoubtedly be beneficial in this regard as it will enable the farmers in both diversifying their crop mix and reducing the cost of cultivation. 


\section{References}

Acharya, S. P., Bhatta, G. R. (2013). Impact of climate change on agricultural growth in Nepal. NRB Economic Review, $25,1-16$.

Bradshaw, B., Dolan, H., Smit, B. (2004). Farm-level adaptation to climatic variability and change: crop diversification in the Canadian prairies. Climatic change, 67, 119-141.

Cervantes-Godoy, D., \& Dewbre, J. (2010). Economic importance of agriculture for poverty reduction.

De, U. K. (2003), Changing Cropping System in Theory and Practice: An Economic Insight into the Agrarian West Bengal, Indian Journal of Agricultural Economics, Vol. 58, No. 1, Jan-March.

De, U.K. (2013), Infrastructural Growth, Farm Size and Pattern of Crop Diversification Across the Districts of West Bengal, Global Journal of Science Frontier Research Agriculture and Veterinary, Vol. 13, Issue No. 1, Version 1.0.

De and Chattopadhyay (2010), Crop diversification by poor peasants and role of infrastructure: Evidence from West Bengal, Journal of Development and Agricultural Economics Vol. 2(10), pp. 340-350.

Dorjee, K., Broca, S., \& Pingali, P. (2003). Diversification in South Asian agriculture: trends and constraints. ESA Working Paper No. 03-15 The Food and Agriculture Organization . http://www.fao.org/: http://www.fao.org/3/a-ae048t.pdf

Ellen, W., \& Barry, S. (2005). Climate Change Adaptation in Light of Sustainable Agriculture. Journal of Sustainable Agriculture, $113-123$.

Food and Agriculture Organization of the United Nations. (2020). FAOSTAT statistical database. [Rome] :FAO

Fraser, E. D. (2006). Crop diversification and trade liberalization: Linking global trade and local management through a regional case study. Agriculture and Human Values, 23, 271-281.

Jha, B., Kumar, N., \& Mohanty, B. (2009). Pattern of agricultural diversification in India. Inst. of Economic Growth, Unvi. of Delhi Enclave.

Joshi, P. K., Gulati, A., Birthal, P. S., \& Tewari, L. (2003). Agriculture diversification in South Asia: patterns, determinants, and policy implications. International Food Policy Research Institute. May 13, 2020 tarihinde https://www.ifpri.org/publication/agriculturediversification-south-asia

Joshi, P. K., Gulati, A., Birthal, P. S., \& Tewari, L. (2004). Agriculture diversification in South Asia: patterns, determinants and policy implications. Economic and Political Weekly, 2457-2467.

Kishore, A., Pala, B. D., Joshia, K., \& Aggarwal. (2018). Unfolding government policies towards the development of climate smart agriculture in India. Agricultural Economics Research Review, 123-137.

Lin, B. B. (2011). Resilience in agriculture through crop diversification: adaptive management for environmental change. BioScience, 61, 183193.

Ministry of Finance, Government of Nepal. (2018). Budget Speech of Fiscal Year 2018/19 . Kathmandu: Ministry of Finance , Government of Nepal.

Nepal Agricultural Research Council. (1995). Country Report to the FAO International Conference on Plant Genetic Resources . Kathmandu: Nepal Agricultural Research Council.

Popkin, B. M. (2015). Nutrition transition and the global diabetes epidemic. Current diabetes reports, 15, 64.

Rapsomanikis, G. (2015). The economic lives of smallholder farmers: An analysis based on household data from nine countries. Food and Agriculture Organization of the United Nations, 1-39.

Secretariat of the Convention on Biological. (2005). The Impact of Trade Liberalization on Agricultural Biological Diversity: Domestic support measures and their effects on agricultural biological diversity. CBD Technical Series No 16 ed. Montreal: CBD.

Sharma, K. C. (2020, May 03). Crop Diversification in Nepal. Food and Agricultrual Organisation: http://www.fao.org/3/x6906e/x6906e09.html

Shoffner, A. V., \& \& Tooker, J. F. (2013). The potential of genotypically diverse cultivar mixtures to moderate aphid populations in wheat (Triticum aestivum L.). Arthropod-Plant Interactions, 7, 33-43.

Thapa, G., Kumar, A., \& Joshi, P. K. (2017). Agricultural diversification in Nepal: Status, determinants, and its impact on rural poverty (Cilt 1634). Intl Food Policy Res Inst.

The World Bank. (2020, May 02). Nepal: Irrigation and Water Resource Management. The World Bank: https://www.worldbank.org/en/results/2014/04/11/nepal-irrigation-and-water-resource-management adresinden alınd

Wall, E., \& Smit, B. (2005). Climate change adaptation in light of sustainable agriculture. Journal of sustainable agriculture, $27,113-123$. 